\title{
Education for Liberation: Nigeria Experience
}

\author{
Ayeni, M. A. \\ Department of Educational Foundations and Management, Faculty of Education Ekiti \\ State University, Ado-Ekiti, Nigeria
}

\begin{abstract}
The rapid development of science and its influence on our ways of thinking and our beliefs makes education for liberation an important topic for discussion. Nigeria is undergoing a process of democratisation since 1999. And if Nigerians are to be democratically governed they must take share in responsibilities and understand what is going on in order to make personal judgments. This implies that Nigerians must understand the world they live in outside their own small circle of activity. This paper attempts to explicate 'Education for Liberation' as important dose that can make Nigerian people discover themselves, their potentialities, remove themselves from religious bigotry, fear, superstition and poverty and have the ability for scientific thinking through which they can take objective decisions in all spheres of life.
\end{abstract}

\section{Introduction}

The word liberal, etymologically, emanated from the Latin word 'liber' which means 'free' and the plural 'liberi' which meant 'free men'. The verb 'liberate' means 'to free' and the abstract noun 'liberatas' means 'freedom'. There is no possible interpretation of the word 'liberal' which is more or less than 'freedom'.

The primary aim of western education anywhere in the world is related to the fact that human personality should develop freely, guided by reason rather than limited by artificial constraint. This is connected in terms of individual rights and individual responsibilities, of moral responsibility and moral freedom. On the contrary, the minds of the early peoples in Nigeria were fettered by superstition, which caused timidity in the individual who was not free to develop as his western counterpart. In some part of Nigeria religious dogma were and are still constraints on individual thinking and freedom of thought, and because the constraints dominate thinking, they also determine behaviour. The individual acted out in blind obedience, not because he is guided by reason. Education and of course western education is concerned to free the mind from error. Lloyd [6] believed that intellectual freedom will naturally and automatically result in rational behaviour. Intellectual freedom enables people to follow the argument wherever it leads, and to reach conclusions in the light of reason. Reason frees the mind from ignorance. This implies that if a man knows the difference between right and wrong, he will automatically do what is right, because to do wrong in this situation would be irrational. The conviction is that education aims ultimately to enable the individual to make free choices on, for example, moral issues, rather than habituate him to make correct responses without really understanding the reason for his choices. In this respect, education is a liberating agent for individual. The mind has to be freed from error of thinking that knowledge is based on superstition and religious dogma which is still a predominant phenomenon in Nigeria society today. This is however, evidenced by incessant bombing and killings caused by indoctrinated religious fanatics in some parts of the country. As at the time of writing this paper, Christians in some northern states of Nigeria are no more free to go to the Church as they like, some who risked their lives to do so, were no more alive to witness the consequences. Thus education for liberation makes men to be free and remain somebody who lives according to the dictate of reason alone. People have to understand that freedom of action makes responsibility for action inevitable. Only people with liberal minds can understand this paradox.

\section{The Concept of Education}

Dewey [1] defined education as 'the continuous reconstruction or reorganisation of experience which adds to the meaning of experience, and which increases the ability to direct the course of subsequent experience.' Since knowledge comes through the processing of experience by intelligence using the problem-solving method, the aim of education is therefore the development of learners' ability to deal with future problems, that is, the development of his intelligence to solve problems. Education is seeing as the totality of experience in response to nature and environment. In Nigeria for example, there exist three parallel systems of education, namely the indigenous, the Islamic and the western-type. All these supposed to target the development of the child's intelligence towards 
problem-solving. O'Connor [9] was of the opinion that the educational system of any society is a more or less elaborate social mechanism desired to bring about in the persons submitting to it certain skills and attitudes that are judged to be useful and desirable in the society.

Through conceptual analysis, etymologically, education is derived from two Latin words 'Educare' which means to bring up the child physically and mentally and too 'Educere' which means to lead forth or draw out the naturally acquired potentialities in the child. Plato said, by 'Education I mean that training which is given by suitable habits to the first instincts of virtue in children when pleasure and pain are rightly implanted in the non-rational souls. The particular training in respect of pleasure and pain, which leads you to hate and love what you ought to hate and love. Plato's definition is questionable because education and training have got their own logical boundaries. But it is noteworthy to see that Plato's definition of education has a moral emphasis since it talks about 'good' and 'bad', 'pleasure' and 'pain'.

Milton [7] defined education as the one 'which fits a man to perform justly, skilfully and magnanimously, all the office, both public and private, of peace and war'. What Milton was saying is that if you know everything, you can do everything, it implies that education should train someone in veracity and adaptability, the essence of which education stands for.

From the above definitions, one can see that education is a member of a class of concepts, describing certain processes such as teaching, learning, training, instruction, indoctrination and so on. In undertaking these processes, the end result is anticipated or achieved. This end result is generally referred to as educated person; such a person is expected to have mastered certain skills to be cultured, and above all, to possess a trained mind. It is of course obvious that the concept of an educated man varies from one civilisation or culture to another and from generation to generation. Thus the superior man of Confucianism, the guardian of Plato, the classical humanist of Erasmus, Rousseau's natural man, the Mallams and Khadis of Islam, the Omoluabi of Yorubas, the literate, numerate and scientifically well-informed individual of the contemporary world, among others were or are the paragons of knowledge and wisdom in their respective cultures.

A closer examination of the definitions of education given above reveals that they have certain common features which are pointers to what the essence of education consists in. they all, implicitly or explicitly, harp on the centrality of the acquisition of knowledge, skills and attitudes considered useful and desirable in a particular society. From the above analysis, one can submit that the essence of education consists not necessarily only in, but above all the acquisition of a trained mind. If this is the target of education, one can therefore examine the relevance of education in the society.

\section{Education and the Society}

The purpose of education is to reinforce the social ethics existing in the particular society, and to prepare the children and the young people for the place they have in that society.

Dewey [1] believes that the individual and society are inseparable, that one cannot exist without the other, rather does each exist in utter independence of the other. As Dewey puts it, 'There is inherent opposition between working with other and working as an individual. The individual and the society exist in a sort of experimental continuum.' Thinking or any other intellectual organisation is not an end itself, but is the means by which social relations may be understood and more intelligently ordered. Here then is the essence of education as a liberating agent. As Dewey has put it, 'The heart of the society of man is in education', the freedom of man lies in education and in more education. Education makes it possible to transverse the dualism of the individuals and the society to arrive at a continuum. Specifically, education is necessary for the individual to express his freedom intelligently and with foresight to organise and interact with his environment; and it helps to free individual capacity in a progressive growth. So, Dewey's solution is more and more in education. It is a very optimistic view, and implicit faith in the power of education. It is an undoubted fact that education is valuable. Gellner [5] have identified certain functions prerequisites which are necessary for the survival/continuum of any human society. These prerequisites are the six social institutions: the family, the educational system, the economy, the political system, the health/welfare system and the religious/moral system. Thus whereas the family ensures that the population is reproduced, failing which the group will perish, the educational system ensures that the population is also reproduced culturally and socially by ensuring that children learn skills and values that will enable them function adequately as adult. Similarly, the political system ensures the maintenance of law, order and security within the polity. The economy, health/welfare system and the religious/moral system play their respective roles in the areas of production of goods and services, health and reinforcement of the society's sense of meaning and purpose in life.

Education, according to Saunders [11], is an instrument of social change. Social change is a process wherein the patterned networks of rules or institutions are modified, re-adjusted or radically transformed to provide new sets of guidelines for social behaviour and structure. Institutions are 
seldom static. There is always a dynamic feature about them. A great deal of 'social engineering' goes on in Nigeria and all this is an attempt to create the kind of society which best suits the needs of the greater majority of the people. To this end, the position of education in the society becomes inevitable whether it is a sin as claimed by some people or not.

\section{Education as a Liberating Agent}

The educational system of any society is a more or less elaborate social mechanism designed to bring about in the persons submitted to it certain skills and attitudes that are judged to be useful and desirable in the society. In other words, it develops a worthwhile behaviour that makes the recipients become an acceptable member of the society in which he finds himself.

As a matter of fact, education is unquestionably a constant process for the liberation of human beings. It is liberating in the sense that it enables people to overcome injustice, poverty and fear. Education is not only an important tool for day-to-day management of human problems. It is also what enables people from the underdeveloped part of the world to stand against injustice and fear. It does not only empower people against taboo and superstition but also useful as an instrument for crushing ignorance. In line with the above, it is an undoubted fact, that education creates a learning process which aims at liberating people in the society from their external and internal oppression and to make them capable of changing their reality, their lives and the society they live in.

Education as a liberating agent has the focus and the target of addressing the dichotomy and disparity created through gender inequality, especially in the developing countries like Nigeria, thereby reducing to a reasonable level gender imbalances in the country's socio-political terrain. Education also serves as a means by which people discover themselves and their potentials as they have power and control over things around them, as Freire [4] puts it, each individual wins back the right to say his or her own word, to name the world. Thus, in Nigeria for example, when an illiterate or semi-illiterate adult participates in Sandwich or Part-Time educational programmes, on graduation he or she comes to a new awareness of self, has a new sense of dignity, and is stirred by a new hope. The recipient now realises that he/she is now a new person, an educated person. Before this period, he sees himself as blind, but now his eyes have been opened, before the educational programme, words meant nothing to him, now they speak to him and he can make them speak. He now sees himself no longer a dead weight in the sociopolitical and ethno-cultural terrain of his nation; he can now raise his voices out to condemn or commend the activities of the oppressors. When this happens as a result of education, man and women discover that they are creators of culture and that all their work can be creative. His new life now is that of participating in the transformation of his immediate environment.

As in Nigeria, for example this category of illiterate groups that has been completely marginalised before, are now radically transformed, they are no longer mere objects, responding to changes occurring around them; they are now more likely to decide to take upon themselves the struggle to change the structures of society, which until now have served to oppress them as a result of their ignorance and narrow mindedness. Thus education as a liberating agent in this sense promotes an awakening of political consciousness that is arguably the first step to actual empowerment, specifically through changes in media consumption, internet awareness, increased objective political knowledge and increased dissatisfaction with political oppression and feudal lordship in the third world countries like Nigeria. It is an undisputed fact that education central role, according to Freire [4] is to bolster the cultural hegemony of ruling elites while simultaneously emphasising that alternative forms of 'popular' education in forms of Sandwich and PartTime education as is the case in Nigeria could be instruments for social change favouring the liberation o the oppressed, that is the illiterates and semi-illiterates that form a significant group of the populace.

\section{Education for Liberation: Nigeria Experience}

Education is an institution. An institution is a patterned network or system of interrelated rules which provides a set of guidelines for social behaviour and structures. Education as institution is an agent of change. Change, in this sense, is a process wherein the patterned networks of rules or institutions are modified, readjusted or radically transformed to provide new sets of guidelines for human behaviour. The pertinent question one could ask is the role education can play in resolving the platonic paradox which is real rather than imaginary in contemporary Nigerian society. As a matter of fact, the role of education anywhere in the world is underlined by the fact that each society establishes an educational system designed to serve its present and future needs, especially in the areas of scientific and industrial techniques and the body politic of the society, that is to say to serve as an instrument for change and renewal. This in every such system, the transmission of knowledge, skills and values is basic.

The knowledge, beliefs, ideas, techniques and values which the educational institutions impacts are those of the larger society. It should be noted, 
however that the principal agent of change or transition is knowledge gained through education. This scientific knowledge that education brings has been obtained through observation and experimentation and has been subjected to sustained critical scrutiny and passed through a many-layered epistemological filter. Only through education can human life hold meaning. The teacher's thinking is authenticated only by the authenticity of the students' thinking. The teacher cannot think for his students nor can he impose his thought on them. Authentic thinking, thinking that is concerned about reality, does not take place in social isolation, but only in education. If it is true that that thought has meaning only when generated by action upon the world, the subordination of students to teachers becomes impossible.

Generally speaking, education according to Dubey [2] affirms men and women as beings in the process of becoming an unfinished, uncompleted beings in and with a likewise unfinished reality. Indeed, in contrast to other animals who are unfinished but not historical, people know themselves to be unfinished, they are aware of their incompletion. In this incompletion and this awareness lie the very roots of education as an exclusively human manifestation. The unfinished character of human beings and the transformational character of reality necessitate that education be an ongoing activity all over the world and Nigeria as a nation can never be an exception.

Human existence cannot be silent, nor can it be nourished by false words, but only by true words given by education, with which men and women transform the world. To exist humanly, is to name the world, to change it, once names, the world in its turn reappears to the names as a problem and requires of them a new naming. Human beings are not built in silence but in word, in work, in action reflection as manifested in the acquisition of authentic education. This authentic education according to Nduka [8] is not carried on by ' $A$ ' for ' $B$ ' or by ' $A$ ' about ' $B$ ' but rather by ' $A$ ' with ' $B$ ', mediated by the world-a world which impresses and challenges both parties, giving rise to views or opinions about it. These views, impregnated with anxieties, doubts, hopes or hopelessness, imply significant themes on the basis of which the programme content of education can built.

Education for liberation in Nigeria contexts is to achieve the five principal national objectives such as:

a) a free and democratic society

b) a just and egalitarian society

c) a united, strong and self-reliant nation

d) a great and dynamic economy

e) e. a land of bright and full opportunities for all citizens (NPE, 2004)
By these national objectives, it is apparent that the federal government of Nigeria appeared to be committed to a fundamental change in the intellectual, social, political and economic outlook of the society through education. Alas! It is disheartening to note that the realisation of these objectives seem to be too far from actualisation as a result of the inability of the same government to implement the policy. This shortcoming on the part of the government reveals Nigeria as a country that is economically, industrially and educationally underdeveloped in spite of the government efforts through different programmes to boost agricultural production and in spite of the fact that weather is naturally in our favour, Nigeria still import food to feed the populace. Our poor health services coupled with the deplorable sanitary condition, make life almost unbearable in some parts of the country.

In place of the much-talked-of just and egalitarian society, Nigerian society, is a society of glaring inequalities, sanctioned and supported by a capitalist system which has been thriving on corruption, fraud, inflation, robberies both armed and unarmed and insecurity posed by religious fanatics.

The function of education in this regard is to foster mutual understanding among Nigerians and strengthen the bonds of fraternity, among the various ethnic, religious and socio-economic groups-all with a view to developing national consciousness. Education for liberation should assist in the gigantic task of developing the human and material resources of Nigeria, and equally important is the fact that various approaches must be devised to overcome the reluctance of the Muslim communities in the northern part of Nigeria to receive western education, which some religious fanatics see as a sin, as a key factor in the liberation of the society from religious dogmatism, docility and even fanatism.

\section{Conclusion}

Education for liberation seems to be the target of Peters when he says that education involves the transmission of what is worthwhile, that education picks out no one process or method, that education does not merely instruct, but develops understanding through the giving of reasons. Also that education for liberation puts the learner in a position where he is able to develop his own critical powers. Peters equally submit that education rules out some procedures because they rob the learners of wittingness and voluntariness.

This appears to apply to such methods as indoctrination which is a predominant phenomenon in Nigerian society. But education could also rule out those less emotionally joined methods, such as drill and parroting. These are illiberal when they do nothing to create insight in the mind of the learner. They rob him of the opportunity to make what he 
learns meaningful to him. Uncritical acceptance cannot be liberal.

Reason and the use of reason liberate the mind from unthinking acceptance. Education for liberation as perceived in this paper is faced with the task of encouraging more people to aim for the comfortable life, not only in terms of physical comforts but also in terms of emotional satisfaction. Such a task will involve initiating men into the general culture to help free the mind from the confines of the sub-culture in some respects is inhibiting and stultifying. It will involve encouraging people to make the best use of their abilities and not to think that occupation is solely determined on a class basis.

Education for liberation should focus on bringing the large majority of our people face-to-face with reality. It has to wean them from the familiar and introduce them to the unfamiliar. The mind should be liberated from the yoke of fear, ignorance, poverty and superstition to the regime of light through critical thinking; thus, as Peters submitted, education must not merely provide knowledge which is inert.

Therefore, education should be acknowledged to be a dynamic part of change to which it contributes a sense of commitment or purpose, no matter how many reservations may be felt because of the need to preserve 'creative uncertainty'. Clearly, the future of Nigeria as a nation in diversity depends on her productive capacity and the training given to her citizens in the realm of scientific thinking which is the focus of education for liberation.

\section{References}

[1] Dewey, John (1916). Democracy and education. New York: Free Press.

[2] Dubey, D. L. (1979). An introduction to the sociology of Nigerian education. London: Macmillan.

[3] Federal Republic of Nigeria(2004). National policy on education. Lagos: Federal Ministry of Information.

[4] Freire, Paulo (1972). Pedagogy of the oppressed. Harmondsworth: Penguin.

[5] Gellner, E. (1991). Plough, sword and book: The structure of human history. London: Paladin Grafton.

[6] Lloyds, Gunthis (2009). New lesson: The power of educating adolescent girls. New York: Population Council.

[7] Milton, O. S. (1957). The concept of education (ed.). London: Routledge and Kegan Paul.

[8] Nduka, O. A. (2006). The roots of African underdevelopment and other essays. Ibadan: Spectrum.

[9] O'Connor, D. J. (1957). An introduction to the philosophy of education. London: Routledge and Kegan Paul.
[10] Peters, R. S. (1967). The concept of education (ed.). London: Routledge and Kegan Paul.

[11] Saunders, Doug (2011). A self-taught democracy emerges from Tunisia’s classroom: The globe and mail. 